\title{
Biological and chemical control of nematodes in Capsicum annuum L.'
}

\author{
Nydia E. Vicente' and Nelia Acosta
}

\begin{abstract}
A field experiment was conducted at the Isabela substation. The objective of the study was to compare the effect of the fungus $P$. lilacinus (added 1 week before planting or at planting) and the nematicide carbofuran (IX or $2 X)$ on yields of pepper and on the population levels of $M$. incognita and $R$. reniformis. Significantly more and heavier fruits were obtained from fungus ( 1 week before planting)-and carbofuran $2 X$-treated plots than from the check. A similar frend was observed in the nematode population dynamics; although the percentage of nematode reduction was high in all treated plots, it was higher in those treated with the fungus 1 week before planting and with carbofuran $2 X$.
\end{abstract}

\section{RESUMEN}

Control químico y biológico de nematodos en pimiento, Capsicum annuum

L.

Se realizó un experimento de campo en la subestación de Isabela para comparar el efecto del hongo biocontrolador de nemátodos $P$. lilacinus (aplicado antes de sembrar y al sembrar) y del nematicida carbofuran (IX y $2 x$ ) en los rendimientos de pimiento y en los niveles poblacionales de Meloidogyne incognita y Rotylenchulus reniformis. Se encontraron diferencias significativas en el número y peso de frutas en las parcelas tratadas con el hongo ( 1 semana antes de sembrar) y con la dosis alta de carbofuran (2X) al comparar con el testigo sin frałar. Un tendencia similar se observó en la dinámica poblacional; ya que aunque el porcentaje de reducción de nemátodos fue alto en todas las parcelas tratadas, fue mayor en los tratados con hongo 1 semana antes o con carbofuran $2 \mathrm{X}$.

\section{INTRODUCTION}

Pepper (Capsicum annuum L.) is one of the major vegetable crops in the island. Local production during 1989-90 reached 5,250 tons whereas $2,035.5$ tons was imported ${ }^{4}$. Therefore, pepper production must be increased. Peppers are subject to attack by various pests, including nematodes, insects, fungi, bacteria and viruses. The root-knot nematode (Meloidogyne incognita) and the pepper weevil (Anthonomus eugenii Cano) are among the most detrimental (2).

'Manuscript submitted to Editorial Board 7 October 1991.

"Assistant Nematologist, Department of Crop Protection.

${ }^{3}$ Nematologist, Department of Crop Protection.

"Telephone communication with "Oficina de Estadisticas Agrfcolas, Departamento de Agricultura." San Juan, Puerto Rico. 
Varela (10) demonstrated that $M$. incognita caused chlorosis and stunting of cooking peppers cv. Blanco del País and Cubanelle. Abreu and Cruz (1) found that $A$. eugeniz Cano can cause considerable losses to cooking peppers in the Isabela area.

Nematode and insect control is a feasible alternative to improve and increase peppex production $(2,5)$. Román et al $(9)$ obtained yield increases of 66 and $89 \%$ in pepper production with applications of phenamiphos at 11.2 and $16.8 \mathrm{~kg} / \mathrm{ha}$, respectively. With $1.12 \mathrm{~kg} / \mathrm{ha}$ of oxamyl, Acosta et al. (2) obtained $81 \%$ nematode control, significantly higher yields of $C$. annuum, and significantly lower percentage of fruit damaged by the pepper weevil than with the other treatments. Also the use of biological agents (i.e. Paecilomyces lilacinus (Thom) Samson as means of nematode control has proven effective $(6,7)$.

\section{MATERIALS AND METHODS}

A field experiment was carried out at the Isabela area on a Coto clay (Typic Eutrustox) soil ( $\mathrm{pH}=6.2,1.7 \%$ organic matter) heavily infested with the nematodes Meloidogyne incognita and Rotylenchulus reniformis

The objective of the study was to compare the effect of the fungus $P$. lilacinus and the nematicide carbofuran (Furadan ${ }^{\oplus} 10 \mathrm{G}$ ) on the population levels of $M$. incognita and $R$. Reniformis and on the yield of pepper.

Plots consisted of four rows, $0.30 \mathrm{~m}$ wide $\times 6 \mathrm{~m}$ long. Row spacing and plant spacing were $0.90 \mathrm{~m}$ and $0.30 \mathrm{~m}$, respectively; 20 transplants per row were planted in holes $30 \mathrm{~cm}$ apart along the center of each row. The treatments were fungus $(0.5 \mathrm{~kg}$ per row) added to the soil a week before planting; fungus added at planting ( $0.5 \mathrm{~kg}$ per row $)$, two rates of carbofuran $(0.34 \mathrm{~kg}$ per row at planting plus $0.45 \mathrm{~kg}$ per row added 4 weeks after planting, and $0.68 \mathrm{~kg}$ per row at planting plus $0.91 \mathrm{~kg}$ per row 4 weeks after); and a check (without nematicide or fungus).

The rice granules covered with the fungus were added to the row and incorporated 5 and $8 \mathrm{~cm}$ deep in the soil before transplanting 5 -week-old pepper cv Cubanelle seedlings from a commercial nursery. Carbofuran granules were applied to the row from glass jars by hand and incorporated 5 to $8 \mathrm{~cm}$ deep into the soil with a hoe immediately after planting pepper seedlings. Treatments were replicated four times and arranged in a partially-balanced incomplete block design.

Plants were overhead-irrigated immediately after planting and as needed throughout the season. Control of weeds and fertilizer (10-10-8 at $1120 \mathrm{~kg} / \mathrm{ha}$ ) application was that recommended by the Agricultural Experiment Station for the area (3). Soil samples $\left(250 \mathrm{~cm}^{3}\right.$ per plot) for nematode assays were taken $15 \mathrm{~cm}$ deep before nematicide application 
J. Agric. Univ. P.R. voL. 76, NO. 3-4, JULY/OCTOBER, 1992173

and at harvest 5 weeks after. Nematodes were extracted by the Christie and Perry technique (4).

To prepare the fungus inocula, we soaked $500 \mathrm{~g}$ of commercial polished rice in water for 24 hours. The water was drained off the rice, which was then washed through with sterile water, transferred to a pan and autoclaved at $250^{\circ}$ for 50 min., as suggested by $P$. Jatala from the International Potato Center in Lima, Perú (personal communication). The hot rice was transferred to polyethylene bags, closed and kept on a laboratory bench until cool. The fungus provided by Jatala was originally kept in sterile sand contained in various $10-\mathrm{ml}$ vials. The content of a vial was poured into $125 \mathrm{ml}$ of sterile distilled water. Then a drop of the spore suspension was poured on the rice in each of the plastic bags. The bags with the inoculated rice were kept for 8 to 12 days in an incubator at 28 to $30^{\circ} \mathrm{C}$.

The percentage reduction in nematode soil populations (PRNSP) was calculated for each plot (1). PRNSP is a measure of the effect of a treatment reducing nematode population levels within time lapse in the same plot, where $\mathrm{PRNSP}=\left[\left(\mathrm{P}_{\mathrm{i}}-\mathrm{P}_{\mathrm{f}}\right) / \mathrm{P}_{\mathrm{i}}\right] \times 100$. The variable Pi represents the initial nematode larva population in the soil of a plot-treatment: Pf the final population ( 10 weeks after treatment) from the soil after treatment in the same plot.

TABLE 1.-Effect of $\mathrm{P}$. lilacinus and carbofuran applications on yield and root knot index in pepper

\begin{tabular}{|c|c|c|c|c|}
\hline \multirow[b]{3}{*}{ Treatments } & \multirow[b]{3}{*}{ Dosage } & \multicolumn{2}{|c|}{ Yield/plot' } & \multirow[b]{3}{*}{ Root knot index } \\
\hline & & \multicolumn{2}{|c|}{ Fruit } & \\
\hline & & Number & Weight & \\
\hline & & & $\mathrm{kg}$ & \\
\hline $\begin{array}{l}\text { Fungus, } 1 \text { wk } \\
\text { before planting } \\
\text { Fungus at }\end{array}$ & $500 \mathrm{~g} / \mathrm{row}$ & $81.38 \mathrm{a}$ & $3.70 \mathrm{a}$ & $4.65 \mathrm{a}$ \\
\hline planting & $500 \mathrm{~g} /$ row & $28.05 \mathrm{ab}$ & $1.60 \mathrm{~b}$ & $4.50 \mathrm{a}$ \\
\hline Carbofuran $1 \mathrm{X}$ & $\begin{array}{c}0.34 \mathrm{~kg}+0.454 \\
\mathrm{~kg} / 152 \mathrm{~m}^{3}\end{array}$ & $37.91 \mathrm{ab}$ & $1.98 \mathrm{~b}$ & $4.30 \mathrm{ab}$ \\
\hline Carbofuran $2 X$ & $\begin{array}{c}0.68 \mathrm{~kg}+0.908 \\
\mathrm{~kg} / 152 \mathrm{~m}^{\prime}\end{array}$ & $74.71 a$ & $3.98 \mathrm{a}$ & $3.10 \mathrm{a}$ \\
\hline Check & -- & $9.51 \mathrm{~b}$ & $0.83 \mathrm{~b}$ & $5.00 \mathrm{~b}$ \\
\hline
\end{tabular}

'Means per columns with the same letter do not differ statistically at $P \pm 0.05$, by Duncan's multiple range test.

scale of $0-5$ where $0=0,1=1-2,2=3-10,3=11-30,4=31-100$ and $5=$ more than 100 root galls/root system

${ }^{3}$ Nematicide dosage: $0.34 \mathrm{~kg}$ added at planting plus $0.454 \mathrm{~kg}$ applied 4 weeks later.

${ }^{4}$ Nematicide dosage: $0.68 \mathrm{~kg}$ added at planting plus $0.908 \mathrm{~kg}$ applied 4 weeks later. 

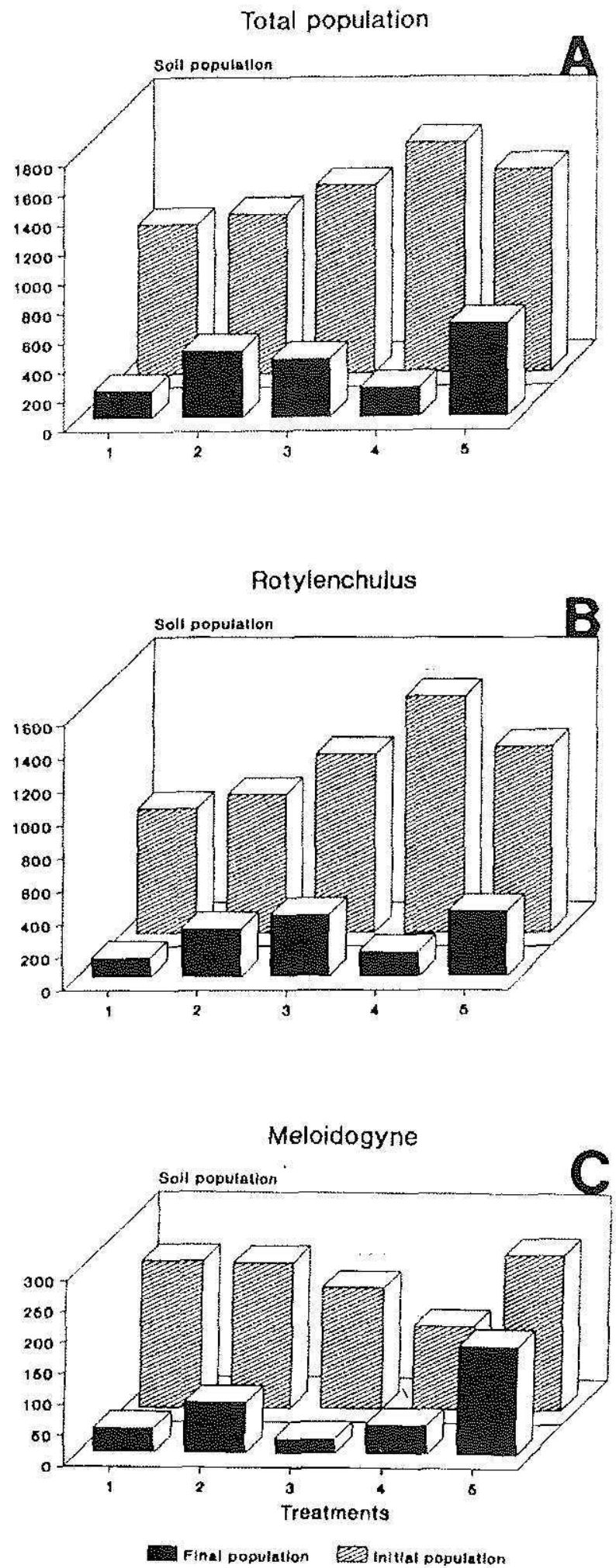

FIG. 1.-(A-C). Fluctuation in nematode population levels in the soil planted to pepper: A) total population, B) Rotylenchulus reniformis and C) Meloidogyne incognita, recovered from plots treated with 1) fungus added 1 week before planting, 2) fungus added at planting, 3) carbofuran $1 X, 4$ ) carbofuran $2 X$, or 5 ) check. 
J. Agric. Univ. P.R. voL. 76, NO. 3-4, JULY/OCTOBER, 1992175

Data on number of fruits, fruit weight, and root knot index, with a $0-5$ scale, were recorded at harvest: $0=0,1=1-2,2=3-10,3=11-30$, $4=31-100$ and $5=$ more than 100 root galls per root system. Data were analyzed following standard statistical procedures.

\section{RESULTS AND DISCUSSION}

Significantly heavier and more fruits were obtained from fungustreated ( 1 week before planting) and carbofuran $2 \mathrm{X}$-treated plots than from the check (table 1). No significant differences were found when comparing these parameters among plots treated with the fungus at planting or with carbofuram $1 X$ and the non-treated; however, values in these treatments were also higher than in the control. These results suggest that the fungus needs more time to become established in the soil before planting in order to give better control. Also in the case of carbofuran, apparently the lower dosage (1X) does not give significant control.

\section{Percent nematode reduction}

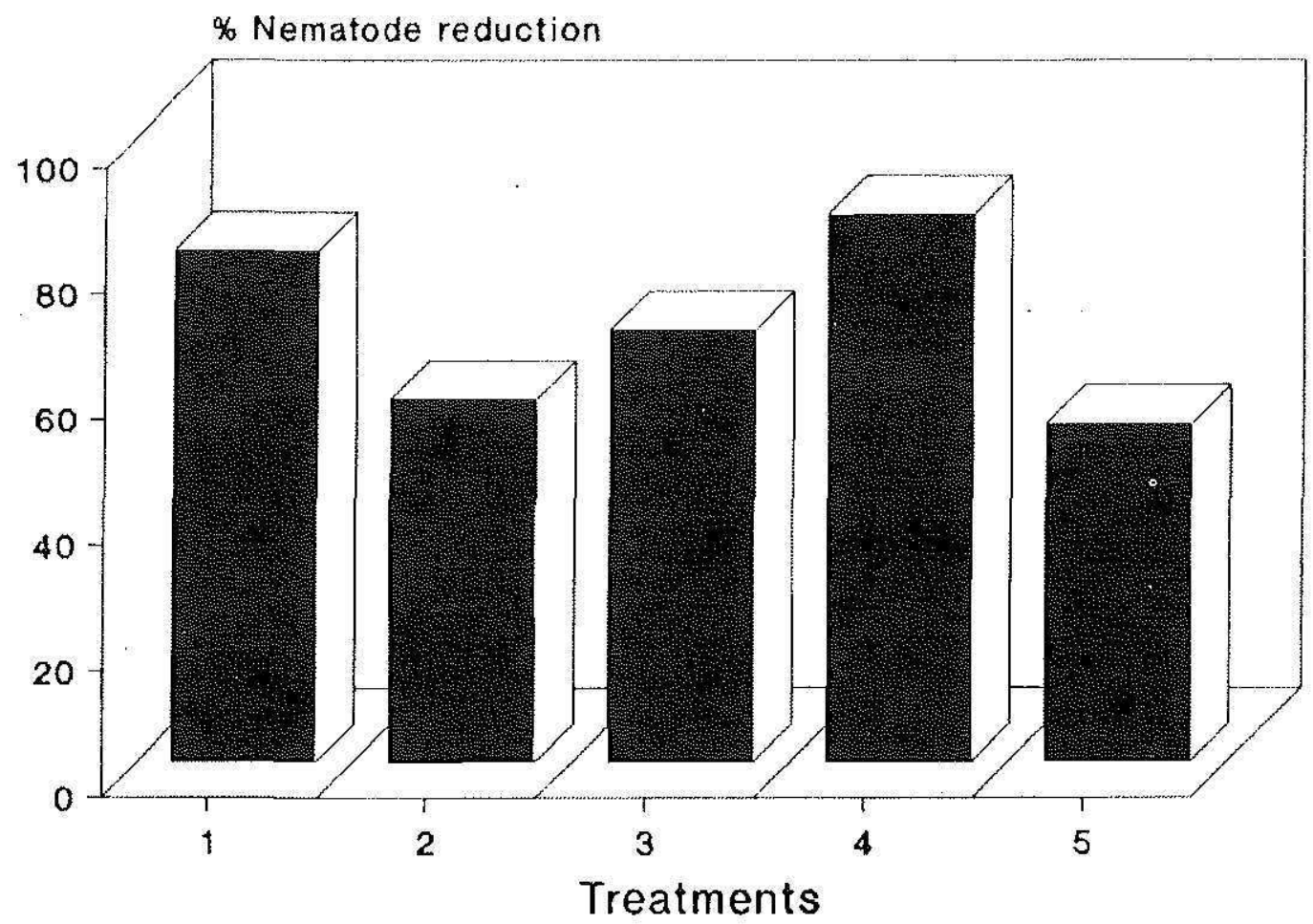

FIG. 2,-Percent reduction in nematode soil populations (PRNSP) is a measure of the effect of a treatment reducing nematode population levels within time lapse in the same plot. $\mathrm{PRNSP}=[(\mathrm{Pi}-\mathrm{Pf}) \mathrm{Pi}] \times 100$ recorded from plots treated with 1) fungus added 1 week before planting, 2) fungus added at planting, 3) carbofuran $1 \mathrm{X}, 4$ ) carbofuran $2 \mathrm{X}$, o* 5 ) check. 
A similar trend was observed in the nematode population dynamics. Both treatments, the fungus added 1 week before planting and carbofu$\operatorname{ran} 2 \mathrm{X}$, were the most effective in reducing the total nematode population (fig. 1A) and $R$. reniformis (fig. 1B). The application of fungus 1 week before planting and carbofuran $1 \mathrm{X}$ were the most effective treatments against Meloidogyne populations (fig. 1C). Significantly lower root-knot indexes were obtained in carbofuran $2 \mathrm{X}$-treated plots than in the check (table 1). The percentage of nematode reduction (fig. 2) was higher in all treated plots than in the non-treated, but much higher in plots treated with the fungus 1 week before planting and carbofuran $2 \mathrm{X}$ than in the check. Lara (8) in field studies with $P$. lilacinus found that the reduced number of nematodes in the soil decreased as the time of inoculation of the fungus previous to planting was increased.

\section{LITERATURE CITED}

1. Abreu, E. and C. Cruz. 1985. Occurrence of pepper weevil, Anthonomus ougenii (Coleoptera:Curculionidae), J. Agric. Univ. PR 69(2): 223-24.

2. Acosta, N., N. Vicente, E. Abreu, and S. Medina-Gaud. 1987. Chemical control of Meloidogyne incognita, Rotylenchulus reniformis and Anthonomes engenii in Capsicum annum and C. frutescens. Nematropica 17(2): 163-69.

3. Anonymous, 1979. Conjunto Tecnológico para la Producción de Hortalizas. Esta. Exp. Agric., Univ, PR Rio Piedras.

4. Christie, J. R. and V.C. Perry. 1951 Removing nematodes from soil. Proceedings of Helminthological Society of Washington, 18: 106-08.

5. Cruz, C., N. Acosta, J. Negrón and A. Armstrong. 1984. Evaluation of various pesticides for the control of aphids, mites and nematodes in peppers. J. Agric: Univ. P.R. 68 (4): $457-65$.

6. Jatala, P., R. Kaltenbach, A. J. Devaux and R. Campos. 1980. Field application of Paecilomyces lilacinus for controlling Meloidogyne incognita on potatues. $J$. Nematol. 12: 226-27. (Abstr.).

7. —, R. Salas, R. Kaltenbach and M. Bocangel. 1981. Multiple application and long term effects of Paecilomyces lilacinus controlling Meloidogyne incognita under field conditions. J. Nematol. 13: 445 (Abstr.).

8. Lara, J. 1989. Alternativas Biológicas para el Control del Nemádodo Nodulador de Raices de Tomate en Puerto Rico. M.S. Thesis. University of Puerto Rico, Mayagüez.

9. Román, J., X. Rivas, I. Reyes, and G. Mangual. 1972. Estudios sobre el uso de nematicidas en hortalizas. Nematropica 1: 23 (Abstr.).

10. Varela, F, 1983. Interacción de Meloidogyne incognila y Fusarium solani en la marchitez del pimiento (Capsicum annuum L.) M.S. Thesis, University of Puerto Rico, Mayagüez. 